\title{
HYBRID TRADITIONAL DWELLINGS: SUSTAINABLE SYSTEMS IN THE CUSTOMARY HOUSE IN NGADA REGENCY
}

\author{
Toga H. Panjaitan ${ }^{1 *}$ \\ ${ }^{1}$ Department of Architecture, Faculty of Engineering, Universitas Indonesia, Kampus UI Depok, \\ Depok 16424, Indonesia
}

(Received: April 2017 / Revised: October 2017 / Accepted: October 2017)

\begin{abstract}
Traditional dwellings have undergone constant change in recent decades as a result of modernization. Though the change is physically visible, a theoretically indiscernible tradition is maintained as a way of sustaining social and cultural systems. A hypothetical assumption asserts that a symbolic cultural value, a 'traditional core,' exists as a sustainable system that functions within a modernized structure. This study begins by identifying the traditional core in question and proceeds to investigate its power over contemporary, modernized forms of dwelling. The study's approach takes on the basic theory of physical change and the key ideas of structuralism. The main findings concern these two interrelated aspects, which are the result of a sustainable system, namely the hybrid dwelling, and the authoritative power that social and cultural systems have over house form.
\end{abstract}

Keywords: Customary house; Hybrid; Modern sao; Sustainable; Traditional core

\section{INTRODUCTION}

\subsection{Customary House}

A traditional dwelling is referred to as rumah adat in Indonesia, or customary house, which is strongly tied to the country's social system (Oliver, 1997; Rapoport, 1969; Waterson, 1995). While a customary house is a living space, it also functions as a social institution, which is generally known as a house society (Waterson, 1990) or clan house (Arndt, 1954). House society was originally proposed in Claude Lévi-Strauss's idea of sociétés à maison. Waterson cited Lévi-Strauss's idea as "a corporate body holding an estate made up of both material and immaterial wealth ... considered legitimate as long as this continuity can express itself in the language of kinship or of affinity and, most often, of both" (Lévi-Strauss in Waterson, 1995: $p$ 49). In this respect, the house reaffirms Rapoport's (1969) socio-cultural determinant in that it signifies the material and immaterial interdependency applied in any customary house. Cultural rituals shaped the space/place where people practiced their daily customs_and consequently, brought the place to claim its significant existence in society (Pearson \& Richards, 1997).

As societies are exposed to modernization, their traditional dwellings also adapt to current demands. It is acknowledged that traditional dwellings continue to change their architectural form (Philokyprou, 2015; Rapoport, 1969; Tjahjono, 2003) amid the massive conservation movements in various countries. While the majority of societies convert their inherited living places, the minority adopts modern living while sustaining their own cultural values (Kotharkar \& Deshpande, 2012) in an attempt to keep the social system operative. These values are often

\footnotetext{
*Corresponding author's email: toga.panjaitan@ui.ac.id, Tel: +62-21-7863512, Fax: +62-21-7863414
} Permalink/DOI: https://doi.org/10.14716/ijtech.v8i5.866 
crafted into the structure of the space/place.

In an object's process of material change, there is a substance, which persists within the newly transformed object. Aristotle's physical theory of change (Allan, 1957) apparently applies to vernacular dwellings that undergo modern transformation. The structural transformation of the vernacular dwelling corresponds to the dynamic social adaptation to the current internal and external conditions. In the social phenomenon of change and continuity, certain cultural values analogously persist to ensure the social system continues. Pearson (1997) describes the dwelling as being modified continually as the societal actions that constitute them change.

The objective of this paper is to identify the traditional core and investigate its positioning power in structuring the new, hybridized house. The research object is the traditional dwelling of the Ngada people and other ethnics in Flores Eastern Indonesia. The place of the investigated dwelling is located in the traditional village of Borado in the Langa District in the Ngada Regency.

\subsection{Sustained Tradition}

This study takes on Aristotle's theory of change (Allan, 1957) and the key features of structure (Piaget, 1970). Aristotle's persistency in the process is analogously a sustainable system in the case of the traditional dwelling and its position in the transformed structure. The term 'sustainable' refers to the hold on or persistency of an entity that makes it possible for the rituals and customs to continue to perform. In this study, the idea of the persistency of an entity refers to socio-cultural ideology rather than being solely architectural. Sustainable issues in vernacular studies have largely focused on building technology (Guy \& Farmer, 2001; Powter $\&$ Ross, 2005), which is naturally understandable since the term has been utilized in building systems; as Philokyprou explains, "The use of traditional local materials and available resources and also the incorporation of many bioclimatic features in the design of the traditional settlements give them a sustainable identity" (2015: p.4). The term 'sustainable' also applies to the immaterial, which in this case refers to the socio-cultural ideology of the society concerned (Vellinga, 2005). However, ideology itself would not be understood, nor would it exist, if it was not materialized, and therefore it cannot be experienced architecturally.
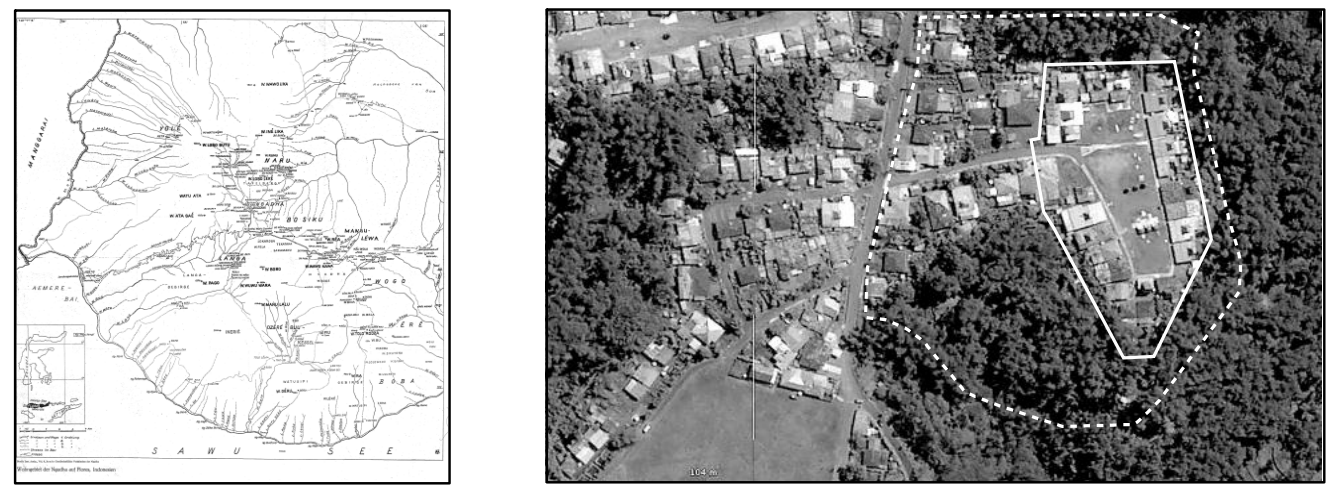

Figure 11927 map of Ngada Regency (left). Kampong Borado in Langa, in solid white lines (right)

The term 'structure' in architecture, as in other building engineering disciplines, is well defined in regard to building systems. It is a platonic structuralism, where structure is defined as a pattern of connections between elements that constitute a certain entity (Marcussen, 2008). In social anthropology, structure refers to the methodology by which culture should be understood in terms of its relation to a larger system. According to Piaget (1970), a structure is defined as a system of transformations by which the structuring connections come into existence and evolve (Marcussen, 2008). Meanwhile, the key features of Levi-Strauss's structure are wholeness, 
transformation, and self-regulation (Cremes, 1997; Piaget, 1970). The idea of structure in regard to this study is that which holds a transformative building in the modernization process of the traditional sao dwelling, implying that the key features of the structure work as elements in the transformative process of modernization.

\section{METHODS}

This study was conducted in two broad phases. The first identified the presumed existing traditional 'core' (Kotharkar \& Deshpande, 2012), and the second analyzed the transformed hybrid structure of the customary kampong in Borado. The term customary kampong is a traditional village that is built to facilitate the conduct of the social and cultural system. It is prerequisite that the presumed 'core' should show its physical and socio-cultural bond, which is mediated through symbolic attributes or spatial division. The method of identifying the core and structural pattern was conducted through comparative study involving field observation on a number of houses and interviews with several mosalaki (tribal leaders). Since it was not possible to conduct a chronological study over a continuous period of time, the comparative method was conducted based on a non-chronological rationale (Kotharkar \& Deshpande, 2012). The core was identified by determining the basic form from a number of variant traditional houses in several selected old kampongs. Following the identification of the basic form, a number of customary houses of modern structure in the kampong were thoroughly examined to determine whether the core existed. Examination of the physical structure of the modern houses revealed a pattern of spatial organization related to the position of the core. Interviews were conducted with the owners as well as the builders to understand the design and construction process. The content of the interviews concerned the hybridization of vernacular tradition with the application of modern technology.

\section{DWELLING, CHANGE AND SUSTAINABILITY}

The hybrid form of the customary sao houses of the Ngada ethnic people is a result of a sustainable system imposed on the process of transformation. The system is, in principle, a set of rules that the construction of the structure and the spatial organization of a customary house should follow. The rules are the concretization of Ngada's cosmology and mythology, reflected by the sao, which hold the social and cultural functions within a traditional settlement. The implementation of the rules in physical form therefore enforces the cultural and social system.

The issue of a sustainable system in regard to hybrid form implies that the authoritative power of the rules result in a fusion of the traditional-modern model with cultural values in both the structure and the way of living. The traditional builders and the inhabitants unconsciously adapt to these rules, which form a strong precedent for the structural patterns, such as symmetry, centrality, and hierarchy, in the modern model of a customary house.

The Ngada customary house appears to be conforming in its social function to Levi-Strauss's idea of house society. The Ngada ethnic group practices a matrilineal system that serves as a framework for the social structure of the house, as regulated by members of the clan.

The whole spatial organization of the sao appears to be the primary determining factor for its later development. The sao's position as a house in society holds a firm place amid the transformation because of the symbolic significance of the hierarchical system it possesses in the form of spatial sequences. The spatial division expressed in the successive three independent structures represents the house's life cycle, which places the sao oné as the oldest structure, and consequently, it possesses a sacred quality. The sacred place of the Ngada generally refers to the presence of the ancestors in that particular space. However, the sao oné's presence in society is more significant than being associated only with ancestors; it is also the 
place of origin, which, like other Austronesian cultures stated by Fox (2011), represents inheritance and property-where heirlooms are hung and wealth is hidden, where clan affairs and cultural ceremonies are carried out-all of these rituals and beliefs are packed into this relatively small sao chamber.

The hierarchical formation that indirectly reflects the social system represents the cultural mythology, which emphasizes a veneration of ancestral culture. The Ngada customary house, like most Southeast Asian dwellings, is strongly associated with ancestors. The house is occupied by the living and the dead (Waterson, 1990). The ancestral culture of the Ngada house posits Levi-Strauss's house society as a person or ancestors, whose name and properties are passed down to the descendants in a "line considered legitimate as long as this continuity can express itself in the language of kinship" (Lévi-Strauss in Waterson, 1995).

Hierarchy, descendants, and ancestry appear to have a strong correlation within the social system, which also marks a symbolic classification in the construction of the house. Such traits are demonstrated in a "trunk-tip" (Waterson, 1990) layout of the three independent structures, both vertically and horizontally. The vertical sequences appear to be more distinctively significant than their horizontal counterparts, which, as the axis mundi of the Ngada cosmology, are described in the local saying as "deva zeta nitu zale" (deity above spirit below). A local knowledgeable informant, Ivan Botha said, the siting of a settlement is described as "logo bei wolo wai deri mesi" (Shoulders laid upon the hill, and feet in the sea, is strength). Waterson (1990), in her milestone study of Southeast Asian houses, mentions the "base-tip" and "trunktip" metaphor $(1990:$ p.124, 191) in reference to the construction-mythology analogy of house form (Fox, 2011). Thus, regarding the social system and its cultural value, the house is functioning as a primary part of a larger system in the society.

\section{DESCRIPTION OF THE DWELLING}

\subsection{Basic Structure}

In the Ngada society, the rumah adat is structured as a lineage system, comprising several houses, in sequential order as follows: sao meze pu'u, the main or grand house; sao kaka, first layer supporting house; sao dhai, the second layer supporting house; and sao dhoro, which is a type of common house that bears no customary institution. This paper focuses on the sao meze pu'u, which not only represents the highest social level, its architecture is also a blueprint model for all other ranks below.

Sao meze pu'u, or simply sao, is principally composed of three independent structures that are unified by their interrelationships in a hierarchical order and by their integrated social functions. The three, in successive order, are as follows: teda moa (front open space), teda oné (a midclosed space), and sao oné (a living compartment which is roughly $4 \times 4 \mathrm{~m}^{2}$ ) (Figure 2).

The human life cycle is reflected in the sequential spaces, where every progression is toward the sao oné, signified as moving to higher levels, to a matured state. Thus, the house is believed to be growing old, just like a person.

Among the three, sao oné is the most important because it possesses the sacred quality of a place where the ancestors also reside. Waterson (1990) called this typical Austronesian descendants' dwelling the "living and the dead" house. It holds the inhabitants' material and immaterial wealth (Carsten, 1995), and thus, the chamber is very private and is closely attached to the clan's own properties. Sao one is the most valuable asset in the social system. Its position in building the regulations governing tradition consigns it as the center of the daily life of the society. 

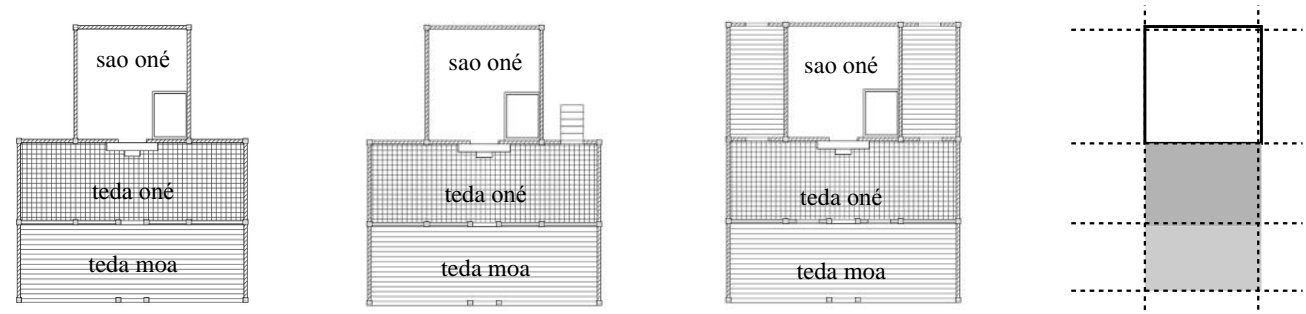

Figure 2 The customary sao varies throughout its development. In this example, spaces were later added around the sao oné chamber

As this traditional house developed overtime, another type of the customary house was built, but these were substantially less in numbers. However, the roof structure remains the same. The ethnic description of the house indicates the model was executed as a result of practicality because of the land limitation, although there is also an element of social reasoning. The reason is associated to the house supporting system known as sao kaka or sao dhai, which are genealogically descended from the main house, in which it is paired with.

This new house, which is called dhaka zwa, is a form of two single houses merged under one main roof structure. Each house has its own pyramid-hipped roof above the sao oné chamber. The houses are different in regard to their social rank, where the main custom house, the sao pu'u, remains slightly larger and is located on the right. Its paired counterpart is the sao kaka, a supporting house in the system, a system known as sao meze saka pu'u.

As the modern house developed, a separated kitchen and later a detached bathroom in either the single or coupled house were added to the main structure. The service facility below illustrates that the houses have changed in response to the way people live. Given the need to expand the customary house, Ngada builders have traditionally added enclosed spaces to the basic sao spatial formation without sacrificing the formation principles.
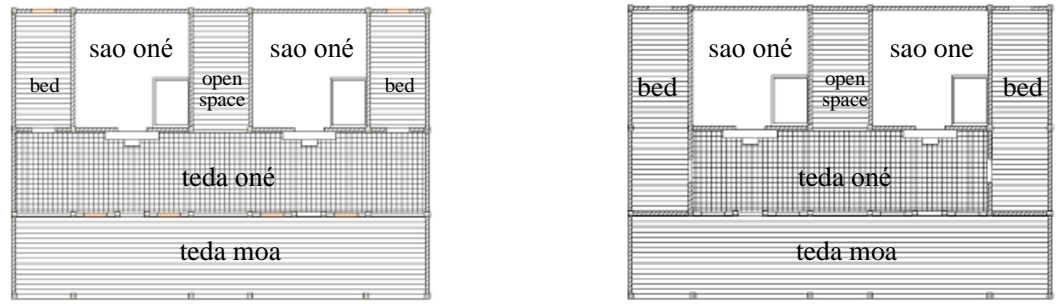

Figure 3 The spatial organization of dhake zua permits an open space between two sao oné

\subsection{Traditional Core: The sustainable System}

The traditional core is a socio-cultural system by which the core, as an immaterial idea, is physically manifested into a structure. Through building observation, a comparative study has identified the traditional core in question.

In as many as five settlements that consist of the oldest and the subsequently developed kampong, this study has found the phenomenon of the traditional core is laid abstractly, on two layers, as the whole and the component. The sao, which is composed of three independent structures, is the totality of the house. Its component formations remain at their original positions, both on a horizontal field and in vertical elevation, continually fixed in the modernized dwelling. This fixed formation appears as the key that regulates any additional spaces or rooms, which results in the setting itself at the center point and positioning it at the front. The formation retains its lifecycle mythology. Although two components have changed 
their physical dimensions and construction material, the sao oné remarkably persists in its construction origins and spatial divisions.
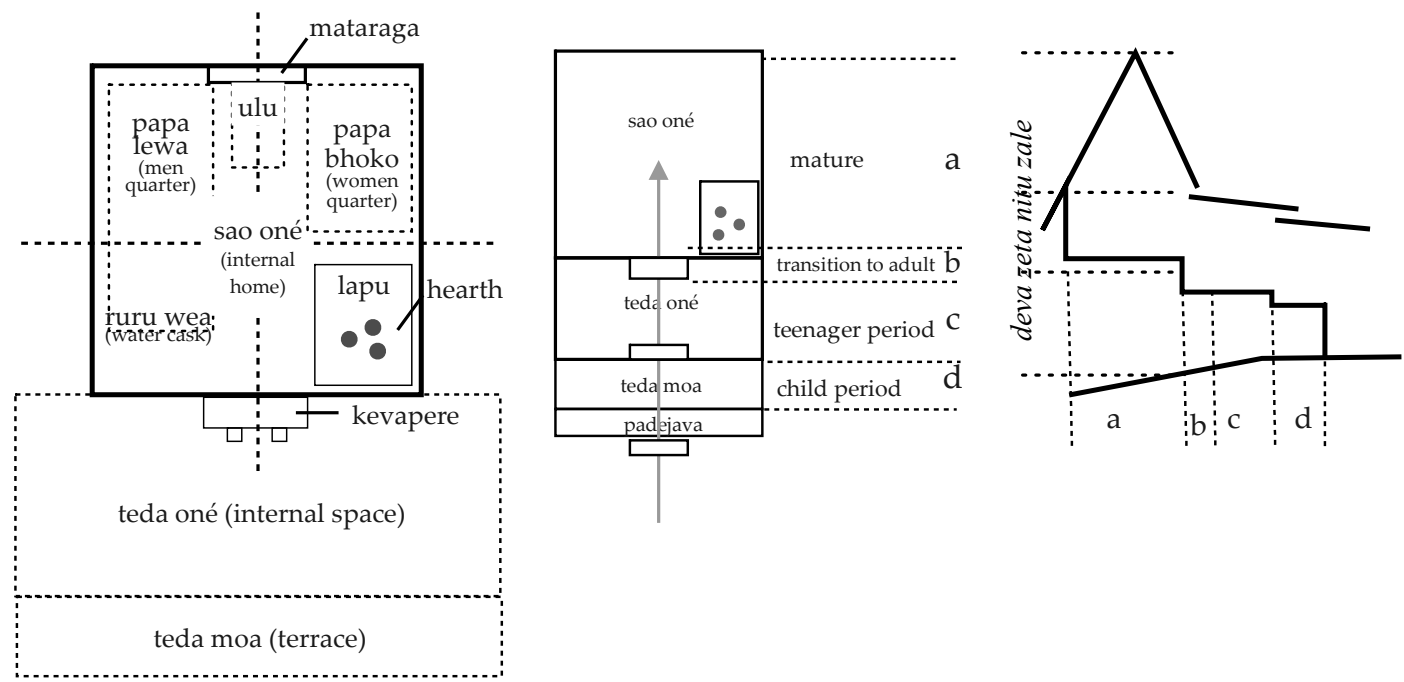

Figure 4 The principle floor plan of a sao pu'u with space division (left). A life-cycle illustration in space arrangement (center). The section in column (a) represents the axis mundi of the house (right)

\subsection{Basic Modern Prototype: The Healthy House}

A prototype of a modern house was first introduced as a healthy house during the Dutch colonial period (Rato, 2009). The concept of a healthy house was first introduced by missionaries and colonists, and after independence it was adopted by the government of Indonesia. The principle of a healthy house was basically a house with many openings to allow the daylight to enter and for cross ventilation between the separation of rooms according to their functions. The spatial organization is simple with divisions between bedrooms and living spaces that also serve for cooking. Another feature is the introduction of a bathroom close by or attached to the main building, but located at the back.

The prototype floor plan of the modern house offered by the government technically consists of $3 \mathrm{~m} \times 3 \mathrm{~m}$ modules. The main building is a combination of four modules, each $9 \mathrm{~m}^{2}$. All other additional rooms or open spaces conform to the modular grid.
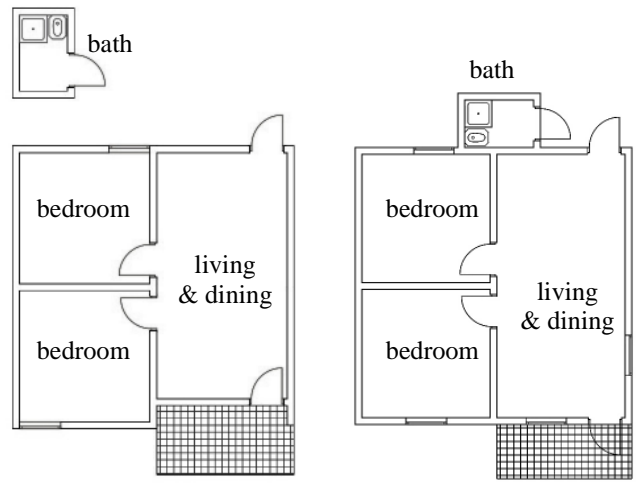

Figure 5 The basic floor plan of a modern dwelling

\subsection{Additive-subtractive}

The term additive refers to the addition of components (space or room) to a given building, while subtractive refers to the reduction of size, structure, or construction. Generally, in catering for the new needs of spaces or rooms, traditional builders modify the existing building by 
adding or removing some construction. In the modernization of the traditional house, Ngada builders have adopted new construction patterns by replicating the selected floor plan of a modern building. Technically, they insert new space into the existing footprint with flexible sizes in mind, therefore creation of a modern dwelling is performed by the additive-subtractive approach.

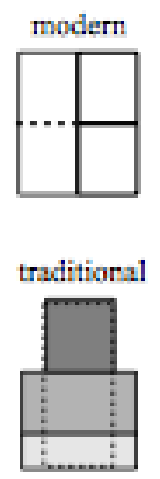

(a)

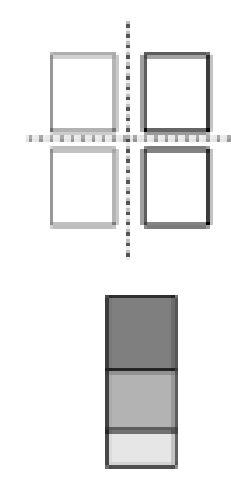

(b)

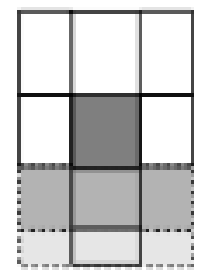

(c)

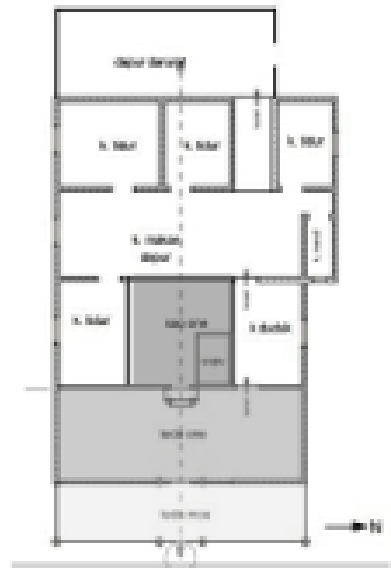

(d)

Figure 6 The components of sao (grey blocks) and the modern healthy house (white blocks)

The components of the sao and the modern, healthy model of the house are distinguished by their order, rigidity and modular flexibility (Figure 6a). As they are combined, the flexible modern modules are locked into the rigid traditional components. A principle form is established, which then allows numerous variants. The sao is firmly rooted at its position and order.

\section{DISCUSSION: HYBRID OF TRADITIONAL AND MODERN DWELLINGS IN THE NGADA REGENCY}

\subsection{Chronicled Brief}

Since the colonial period, the Ngada society has been subjected to salubrious living, based on Western ideas of a healthy dwelling. This design concept was first introduced by European missionaries (Rato, 2009) but was effectively implemented several decades after Indonesian independence was achieved in 1949. The healthy house was then referred to as a modern dwelling, and later the words 'healthy' and 'modern' were used interchangeably to express a non-traditional house. But when the modern is physically integrated with the traditional house, the whole combined house is legitimately called sao pu'u, or sao lobo, each according to its traditional social rank. Sao pu'u refers to 'main house symbolizes ad female, sometimes known as the 'trunk' or 'base', whereas sao lobo refers to main house of symbolize male, known also as 'tips'.

Initially, the Ngada people built healthy houses in their settlements, while keeping the traditional sao at their original places. Thus, traditional sao and modern houses exist as separated structures, independent and autonomous. The modern house has no cultural bond nor social integrity as imposed by the cultural system.

Initially, the Ngada would live in both houses at different times of the day. The reason behind the 'to-and-fro' living was cultural. The Ngada, by customary rule, have a duty to diligently care for the sao oné chamber. Daily duties that keep the householder intensely close to the sao oné include preparing offerings and lighting fires in the hearth all night long. Historically, the 
householder would assemble members of the family clan to perform ritual ceremonies, settle the clan's affairs, or perform other duties that must be done in the sao oné chamber. At other times, the family would live freely from cultural restrictions in the modern house. Currently, householder family matters are occasionally discussed in the modern house.

In later development, the traditional and the modern houses were united as one large dwelling. The unification of the two was largely a practical way to modernize a customary house, which has long been endorsed by the government and the church (Rato, 2009). In addition, some residents consciously reclaim the rights and status of living in one place or in the sao as it was originally built by their ancestors.

\subsection{Building Plan}

When building the modern customary house, the owner discusses his plan with a lima padhe, a master builder, to determine the position of the traditional sao with all other new spaces or rooms. The lima padhe would retain the site where the sao was originally built, and the entire structure conforms according to the traditional rules of construction. Although generally the sao position is fixed at its original site, occasionally the new house may be located somewhere else; however, most houses are close to the previous position and the required legitimate ownership of the land.

The position of the modern house is generally in front of the old sao, but there are other modern houses, which are located behind it. The reason is presumably because of land contours. Traditionally, the Ngada selected sloped land on the side of a hill as their house sites.

\subsection{Ordering and requirements}

Historically, the lima padhe would first build the sao oné chamber in another location, away from the final building site. After the sao oné chamber was done, he would dismantle it, transport it to the site, and re-assemble it in the new location. It was another part of the customary procedures and rules the master builder had to follow. There the sao oné was oriented to the inner open court of the kampong.

The two other components were later positioned before the sao oné chamber, but the dimensions could be smaller than the original typology. In modernizing the sao one chamber, the chamber was lifted off the ground, thus leaving a cavity under the wooden floor. Then the master builder would proceed with arranging the additional rooms around the three sequential sao components. The rooms were organized and built with the healthy house concept in mind. The modern house was furnished with public, private, and service rooms located in their general hierarchical order (in front, middle, and back). Since those modern rooms were not under any customary rules, they were flexible and could be added anywhere in the space, except they were never allowed in front of the sao oné, and their levels must be lower than the sacred chamber. Nevertheless, the lima padhe planned the house with great care so as to retain a symmetrical character, which was inherited from the original customary house. The Ngada people utilized a topology of symmetrical and binary opposition in various construction types to philosophically denote the values of balance and stability, among others.

The modern sao is built on the ground and is no longer built as a stilt structure. But the sao oné chamber remains above the ground, because it still represents the axis mundi cosmology. Still the elevation between the traditional components remains in ascending order; only the modern facilities are adjusted according to the ground plane.

\subsection{Combination}

The two models of houses are not fused or blended nor are they transformed into a completely alien style. They are hybridized. Their footprints are merged, but their morphology has created 
two spatial groups of the sao and the modern house. Each one in the group exhibits its own spatial ordering and individual construction character.

The combination of the two models appears to have effectively gained a preservation/conservation objective, while providing the householder with a healthier environment. However, the sao oné remains dark, as is traditional, because it is enclosed by new rooms. It has no direct connection to natural light or ventilation. The owner may have been unaware of the consequences during the planning stage, but the darkness itself could have been designed deliberately. The sao oné symbolizes a womb with its small door serving as the opening to the space, like the vagina (Rato, 2009). Because the Ngada society practices a matrilineal system, they frequently place the woman in an important position of respect. The Ngada people appear to be very careful in combining the traditional and the modern. They make a clear division so as to avoid overlapping the sacred sao space and the modern profane places.
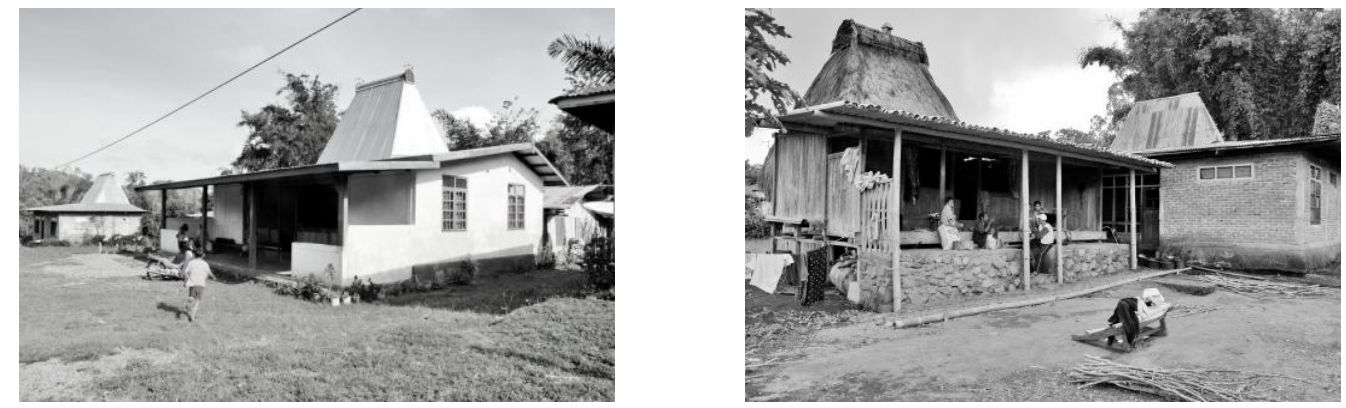

Figure 7 A hybrid model of a custom house (left) and a traditional structure (right)

The above photographs show that the main forms of the modern and traditional buildings are similar from the front facade. However, indoors the hybrid customary house is substantially complex compare to its traditional counterpart.

\section{CONCLUSION}

Much of the concern in the study of vernacular architecture, namely traditional dwellings, is laid upon its gradual disappearance because of intense global modernization. The change in traditional architecture is, on one hand, inevitable, and that brings about deep concerns about conservation failure. However, on the other hand, the phenomenon leads us to look at the architecture in a state of change. This transition brings forward a perspective that breaks up the idea of a fixed vernacular dwelling and initiates an exploration into the underlying sustainable features involved with the constant change of the house.

The findings of the study of the Ngada traditional dwelling in the form of the sao one and the modern house suggest that the transformation is clearly a modernization to both the house form and the traditional way of home living. In regard to the inherited structure, the act of hybridizing a modern dwelling with a traditional customary house calls for spatial complexity. The modern house is required to co-exist with the multi-functional traditional spaces. Thereby, the modern is a pliable component in opposition to the rigid space and place of its traditional counterpart. Pliability and rigidity interplay to show that the idea of the traditional sao is the primary determinant that forms the wholeness of the new house. The new formation exhibits centrality, symmetry, and hierarchy, which suggest the authoritative power of the sao over any potential physical development. The sao architecture and its position of respect within society ensure the continuity of the social system and cultural values. The hybrid architecture is not merely a physical manifestation, but also it embraces a system of preservation/conservation by 
means of an additive-subtractive typology. The transformation process of the modern custom house exhibits the key features of structure: wholeness, transformation, and self-regulation (Cremes, 1997; Piaget, 1970).

The findings of this paper have an implication for future vernacular studies that perceive architecture as a subject in a state of change and not as a fixed material culture. Secondly, previous research by Lévi-Strauss emphasized house society as an abstract concept of a social system, which Carsten (1995) generally found to be the case in social anthropology studies. This paper accepts the idea of house society as a noun that describes a dwelling system. With this position in mind and taking into account the idea of structure, further studies are expected, which will explore the underlying structure or system beneath the physical architectural form.

\section{REFERENCES}

Allan, D.J., 1957. The Philosophy of Aristotle. Oxford University Press

Arndt, P.S., 2009. Masyarakat Ngada: Keluarga, Tatanan Sosial, Pekerjaan dan Hukum Adat. Ende, Flores: Nusa Indah

Carsten, J., Hugh-Jones, S. eds., 1995. About the House: Levi-Strauss and Beyond. New York: Cambridge University Press

Cremes, A., 1997. Antara Alam dan Mitos. NTT: Nusa Indah

Fox, J., 2011. Origins, Ancestry and Alliance: Explorations in Austronesian Ethnography. ANU E Press

Guy, S., Farmer, G., 2001. Reinterpreting Sustainable Architecture: the Place of Technology. Journal of Architectural Education, Volume 54(3), pp. 140-148

Kotharkar, R., Deshpande, R., 2012. A Comparative Study of Transformations in Traditional House Form: the Case of Nagpur Region, India. J Int Soc Study Venarcular Settlements, Volume 2(2), pp. 17-33

Marcussen, L., 2008. The Architecture of Space: The Space of Architecture. Copenhagen: Arkitektens Forlag

Oliver, P.ed., 1997. Encyclopedia of Vernacular Architecture of the World. Cambridge University Press

Pearson, M.P., Richards, C., 1997. Architecture and Order: Approaches to Social Space. London: Routledge

Philokyprou, M., 2015. Continuities and Discontinuities in the Vernacular Architecture. Athens Journal of Architecture, Volume 1(2), pp. 111-120

Piaget, J., 1970. Structuralism. London: Harper Colophon Books

Powter, A., Ross, S., 2005. Integrating Environmental and Cultural Sustainability for Heritage Properties. APT Bulletin, Volume 36(4), pp. 5-11

Rapoport, A., 1969. House Form and Culture. Englewood Cliffs: Prentice-Hall

Rato, D., 2009. Hukum dalam Perspektif Konstruksi Sosial. Yogyakarta: LaksBang Mediatama

Tjahjono, G., 2003. Dwellings of Indonesia: Tradition, Resilience, and Change. Asia's Old Dwellings. New York: Oxford University Press

Vellinga, M., 2005. Anthropology and the Challenges of Sustainable Architecture. Anthropology Today, Volume 21(3), pp. 3-7

Waterson, R., 1990. Living House: An Anthropology of Architecture in South-East Asia. New York: Oxford University Press

Waterson, R., 1995. Houses and Hierarchies in Island Southeast Asia. About the House: LeviStrauss and Beyond. New York: Cambridge University Press 